Vol 1 No 22020 Desember 2020

Jurnal AlphaEuclidEdu

Received: 07/07/2020; Revised: 28/07/2020; Accepted: 02/12/2020

\title{
KESALAHAN SISWA DALAM MENYELESAIKAN SOAL STATISTIKA TIPE HIGHER ORDER THINKING SKILLS
}

\author{
Damayanti, Safrida Dwi, ${ }^{2}$ Hartoyo, Agung ${ }^{3}$ Suratman, Dede \\ 1,2,3 Pendidikan Matematika FKIP Universitas Tanjungpura Pontianak \\ Email: safidamayanti@gmail.com
}

\begin{abstract}
This study aims to inform student errors in solving statistical problems type HOTS (Higher Order Thinking Skills). There are five varians students ability, that are very high, high, medium, low, and very low. This type of research is a qualitative descriptive study. Subjects in the study involved 36 high school students. The object of this research is the students' errors in solving HOTS type statistical problems. Data collection tecniques used are test tecniques and direct communication teniques (interviews). The results resreach obtained are 3 students with very high ability, 12 students with high ability, 10 students with moderate ability, 6 students with low ability, and 5 students with very low ability to solve statistical problems in the HOTS type. Analytical framework for exposing errors using the Newman method. While the data analysis technique uses qualitative data analysis of Miles and Huberman. Whereas the errors made by students are reading errors $(R)$, comprehension errors $(C)$, transformation errors $(T)$, process skill errors $(P)$, encoding errors $(E)$. The mistakes most students make are process skills errors and encoding errors.
\end{abstract}

Keywords: Error, Higher Order Thinking Skills, Statistika

\section{Pendahuluan}

Matematika memegang sebagian besar peran ilmu dasar yang melambari perkembangan ilmu-ilmu lain dan hampir setiap kegiatan manusia berhubungan dengan matematika. Perwujudan kongkrit dalam hal transaksi pembayaran suatu benda yang sering dilakukan oleh setiap orang, tentunya menggunakan berbagai operasi hitung yang ada di dalam matematika. Sejalan dengan ungkapan yang diutarakan Freudenthal (2000:781) yaitu "Mathematics for life on mathematics as a human activities" perwujudan dari matematika dapat dijumpai dalam kehidupan manusia di lingkungan sekitar. Karenanya materi pelajaran matematika menjadi sangat penting untuk diajarkan di sekolah. Peran penting pelajaran matematika tersebut seharusnya mampu membuat pelajaran matematika menjadi satu diantara mata pelajaran yang mengasikkan dan diminati oleh peserta didik. Namun, sampai saat ini masih banyak peserta didik yang berperasaan bahwa matematika sebagai mata pelajaran yang sulit. Hal tersebut mengakibatkan perolehan nilai peserta didik tidak sesuai dengan apa yang diingikan peserta didik maupun orang tuanya.

Laporan hasil Ujian Nasional yang di sampaikan Pusat Penilaian Pendidikan Kementrian Pendidikan Nasional tahun 2019 menunjukkan bahwa capaian rata-rata nilai siswa pada pelajaran matematika dikategorikan kelas bawah, dengan capaian ratarata sebesar $36,54 \%$ dimana mata pelajaran matematika menempati pencapaian rata-rata terendah dibandingkan dengan mata pelajaran lainnya. Untuk hasil pencapaian siswa terendah di Kalimantan barat dicapai dengan skor 0,0 dari skala 0-100 (Pusat Penilaian Pendidikan Kementrian Pendidikan dan Kebudayaan, 2019). Hal ini menunjukan 
Vol 1 No 22020 Desember 2020

Jurnal AlphaEuclidEdu

lemahnya hasil belajar siswa yang disebabkan adanya kesalahan-kesalahan yang dilakukan oleh peserta didik dalam memproses masalah, terutama soal yang menuntut keterampilan berpikir tingkat tinggi atau biasa disebut dengan soal-soal tipe HOTS.

Kebijakan tentang Kurikulum 2013 yang digagas oleh pemeritahan RI melalui Permendikbud No. 22 tahun 2016 tentang standar proses pendidikan dasar dan menengah, bahwa standart kompetensi kelulusan mencangkup pemikiran siswa untuk menganalisis, mengevaluasi, dan mencipta. Hal ini berarti bahwa rancangan penyempurnaan kurikulum diharapkan siswa dapat mengembangkan diri dalam berpikir tingkat tinggi, siswa diharapkan tidak hanya dapat memiliki kemampuan LOTS, bahkan harus sampai HOTS. Menurut Anderson \& Kratwhwol (2001), menyatakan bahwa indikator untuk mengukur HOTS meliputi menganalisis (analyzing-C4), mengevaluasi (evaluating-C5), dan mengkreasi (creating-C6). Menurut Brookhart (2010:3) bahwa HOTS didefinisikan sebagai transfer, sebagai hal dalam pemikiran kritis, serta sebagai hal dalam memecahkan masalah.

Riset penelitian terdahulu yang dijumpai, seperti penelitian yang dilakukan oleh Muhammad Syahwaluddin (2016) menunjukkan bahwa kemampuan berpikir siswa pada tingkat berpikir HOTS pada sekolah MAN 2 Pontianak tepatnya di kelas XI IPA 3 yaitu: tidak ada siswa yang berada pada tingkatan sangat tinggi, 2 orang siswa $(6,25 \%)$ berada pada tingkatan tinggi, 23 orang siswa $(71,86 \%)$ berada pada tingkatan sedang, 5 orang siswa $(15,63 \%)$ berada pada tingkatan rendah, 2 orang siswa $(6,25 \%)$ berada pada tingkatan sangat rendah, ini menunjukkan rendahnya perolehan nilai siswa yang mengakibatkan berlimpahnya kesalahan yang dilakukan siswa dalam menuntaskan masalah tipe HOTS. Hal ini membuat siswa kurang terlatih dan terbiasa, sehingga ketika mereka menemui soal matematika tipe HOTS, mereka sering melakukan kesalahan dan bahkan tidak dapat menyelesaikan.

Dalam proses pembelajaran matematika seringkali ditemukan siswa mengalami beberapa kesalahan. Misalnya kesalahan siswa dalam membaca dan memahami materi atau soal yang diberikan guru. Ketika siswa salah dalam membaca atau memahami soal yang diberikan akan mengakibatkan hasil penyelesaian yang tidak sesuai dengan harapan guru. Menurut Suyitno \& Hardi (2015: 530-532) bahwa tipe Newman salah satu alternatif untuk menentukan tipe kesalahan siswa dalam menuntaskan masalah matematika secara tertulis. Menurut Newman (1977), kesalahan dalam mengerjakan soal matematika dibedakan menjadi lima tipe kesalahan yang berbeda. Lima tipe tersebut adalah kesalahan: membaca (reading error), transformasi (transformation error), memahami masalah (comprehension error), keterampilan proses (process skills error), dan penulisan jawaban akhir (encoding error).

Menurut Singh (2010:266-267) bahwa kesalahan membaca (R) terjadi ketika siswa tidak mampu membaca maupun menuliskan istilah-istilah yang terdapat pada soal, kesalahan memahami masalah (C) terjadi ketika siswa bisa membaca, akan tetapi salah ataupun tidak kuasa dalam menentukan informasi yang terdapat pada soal, serta tidak dapat mencerna apa yang soal tersebut inginkan, kesalahan transformasi (T) terjadi ketika siswa mampu memahami soal, akan tetapi tidak mampu dalam mengidentifikasi 
operasi hitung yang akan digunakan, kesalahan keterampilan proses $(\mathrm{P})$ terjadi ketika siswa tidak bisa menjalan proses perhitungan dengan tepat meskipun sudah dapat menentukan operasi hitung yang sesuai, dan kesalahan jawaban akhir (E) terjadi ketika siswa tidak bisa menuliskan jawaban dengan tepat.

Berdasarkan pengalaman peneliti pada saat kegiatan Praktik Pengalaman Lapangan (PPL) di SMAN 1 Pontianak siswa cenderung melakukan kesalahan dalam menyelesaikan masalah yang menuntut siswa untuk berpikir kritis, metakognisi, dan kreatif dari yang dipelajarinya, Dari hasil wawancara dengan ibu Sri Sukwantini, S.Pd selaku guru matematika kelas XII SMAN 1 Pontianak diperoleh informasi bahwa siswa dapat menuntaskan masalah, ketika siswa diberikan latihan soal yang mudah (soal yang hanya menuntut siswa mengingat, mengaplikasikan, dan memahami). Akan tetapi ketika siswa diberikan latihan soal tipe HOTS, mereka mulai melakukan kesalahan sehingga tidak menyelesaikan soal tersebut dengan benar". Hal ini juga diperkuat dengan hasil pra-riset di kelas XII MIPA 9 SMAN 1 Pontianak yang dilakukan oleh peneliti pada tanggal 27 September 2019 dengan diberikan 5 soal statistika tipe HOTS kepada 36 siswa. Hasil yang diperoleh 21 dari 36 siswa belum mencapai KKM, ini berarti ada $58,33 \%$ siswa yang belum mencapai KKM pada materi statistika. Hal tersebut mengindikasikan bahwa siswa belum mampu menggunakan kemampuan mereka secara optimal.

Statistika adalah satu diantara cabang dari matematika yang berhubungan dengan metode mengumpulkan, mengolah, menyajikan, menganalisis, dan menyimpulkan data (Sembiring, dkk 2012). Statistika merupakan satu diantara materi yang diujikan dalam Ujian Nasional akan tetapi masih ada siswa yang melakukan kesalahan dalam menyelesaikan soal statistika. hal ini sejalan dengan laporan hasil Ujian Nasional yang di sampaikan Pusat Penilaian Pendidikan Kementrian Pendidikan Nasional menunjukkan bahwa persentase siswa dalam menyelesaikan soal sebanyak 38,50\% untuk mata pelajaran aljabar, 36,54 \% untuk mata pelajaran geometri dan trigonometri, dan terkhusus pada materi statistika yaitu sebesar 36,63\%. Hal ini mengindikasikan bahwa siswa masih melakukan kesalahan ketika menyelesaikan soal statistika.

Dari pemaparan yang terperinci diatas, penulis tertambat untuk melakukan penelitian tentang kesalahan-kesalahan yang siswa buat dalam menuntaskan Soal Statistika tipe HOTS. Sangat penting untuk mengetahui kesalahan siswa dalam menyelesaikan soal matematika khususnya pada soal-soal tipe HOTS karena dapat membantu siswa dalam menentukan langkah apa yang diambil selanjutnya agar dapat meningkatkan kemampuan siswa sehingga berpengaruh juga terhadap hasil belajar.

\section{Metode Penelitian}

Dalam penelitian ini, peneliti menerapkan metode penelitian diskriptip kualitatif. Bentuk penelitian yang dterapkan dalam penelitian ini adalah survei. 36 siswa kelas XII MIPA 8 SMAN 1 Pontianak tahun ajaran 2019/2020 adalah subjek dalam penelitian ini. kemudian diambil 10 siswa dari 36 siswa untuk diwawancarai guna mengkonfirmasi analisis yang penelti lakukan, 10 siswa tersebut terdiri dari 2 orang siswa untuk masing- 
masing tingkatan kemampuan yaitu: sangat tinggi 2 siswa, tinggi 2 siswa, sedang 2 siswa, rendah 2 siswa, dan sangat rendah 2 siswa. Kesalahan - kesalahan yang tertuang dalam lembar jawaban siswa merupakan inti dari objek penelitian ini. Tes dan wawancara adalah instrumen yang peneliti pakai untuk mengumpulkan data-data dalam penelitian ini, tes yang diujikan berupa tes tipe HOTS dan kamunikasi langsung pada penelitian ini adalah wawancara. Menurut Miles and Huberman (1991) tindakan dalam analisis meliputi penyajian data (data display) reduksi data (data reduction), serta penarikan kesimpulan dan verifikasi (conclusion drawing/verification).

Pelaksanaan dalam penelitian ini diawali dengan niat dan persiapan, yakni dengan melakukan pra-riset saat PPL 2019, menyusun desain penelitian yang nantinya akan diseminarkan, setelah melakukan seminar desain proposal pada tanggal 13 september 2019 hasil seminar desain proposal direvisi. Selanjutnya untuk kebutuhan penelitian, maka peneliti menyusun instrumen yaitu berupa tes tipe HOTS dan pedoman wawancara. Instrumen penelitian tersebut di validasi oleh satu orang dosen pendidikan matematika FKIP Untan dan satu orang guru matematika kelas XII SMAN 1 Pontianak. Jika hasil validasi tidak valid, maka dilakukan perbaikan instrumen penelitian. Hasil validasi yang sudah layak langsung diuji cobakan pada siswa kelas XII MIPA 3 SMAN 3 Pontianak. Kemudian dilakukan penelitian di kelas XII MIPA 8 SMAN 1 Pontianak. Hasil dari penelitian langsung diolah untuk menjawab rumusan masalah dan tujuan yang peneliti usung.

Kemudian tes yang di kerjakan siswa, peneliti gunakan untuk alat pengumpulan data dalam penelitian ini. Langkah-langkah yang diterapkan oleh peneliti untuk mengolah data yakni: (1) memberikan 5 lembar yang berisi 2 lembar soal statistika tipe HOTS dan 3 lembar jawaban siswa kepada 36 siswa SMAN 1 Pontianak, (2) memberikan koreksi dengan berpedoman pada rubrik penilaian yang telah divalidasi, (3) mengkategorikan hasil pekerjaan siswa ke dalam tingkat kemampuan siswa dan menganalisis kesalahan yang dilakukan dengan berpedoman metode Newman, (4) memilih 10 orang dari masing-masing kategori untuk dilakukan wawancara berupa tanya-jawab guna mengkonfirmasi hasil analisis yang dilakukan siswa, (5) mendeskripsikan hasil tes, analisis, dan wawancara yang telah diperoleh untuk menarik kesimpulan.

\section{Hasil Penelitian dan Pembahasan}

\subsection{Hasil Penelitian}

Penyelesaian soal statistika tipe HOTS yang dilakukan oleh 36 siswa kelas XII MIPA 8 diperoleh data kesalahan siswa pada nomor 1 sampai nomor 5 berdasarkan indikator kesalahan Newman Error Analysis sebagai berikut: 
Vol 1 No 22020 Desember 2020

Jurnal AlphaEuclidEdu

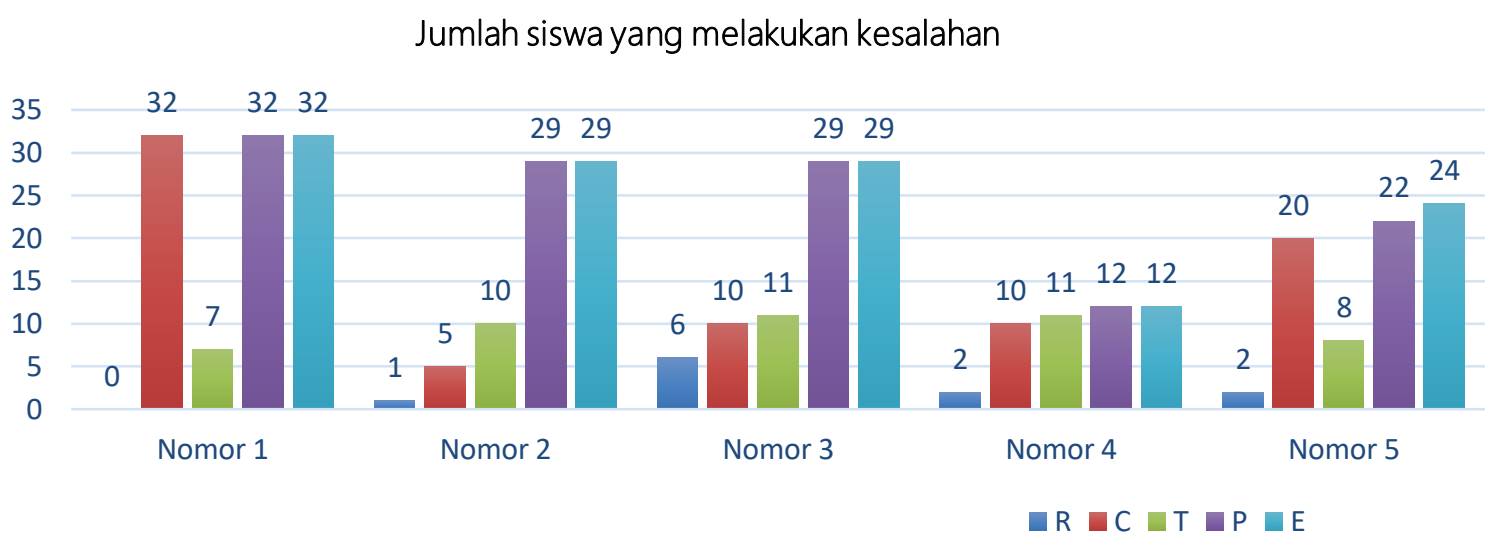

Gambar 1. Kesalahan Siswa Bedasarkan NEA

Berdasarkan gambar 1 diatas dapat diketahui bahwa pada soal nomor 1 jumlah kesalahan tipe $\mathrm{R}$ sebanyak 0 siswa atau $0 \%$, jumlah kesalahan tipe $\mathrm{C}$ sebanyak 32 siswa atau $88,88 \%$, jumlah kesalahan tipe T sebanyak 7 siswa atau $19,44 \%$, jumlah kesalahan tipe $\mathrm{P}$ sebanyak 32 siswa atau $88,88 \%$, dan jumlah kesalahan tipe E sebanyak 32 siswa atau $88,88 \%$.

Untuk soal nomor 2 diketahui bahwa jumlah kesalahan tipe R sebanyak 1 siswa atau 3\%, jumlah kesalahan tipe $\mathrm{C}$ sebanyak 5 siswa atau 13,88\%, jumlah kesalahan tipe T sebanyak 10 siswa atau 28\%, jumlah kesalahan tipe P sebanyak 29 siswa atau $81 \%$, dan jumlah kesalahan tipe E sebanyak 29 siswa atau $81 \%$.

Untuk soal nomor 3 diketahui bahwa jumlah kesalahan tipe R sebanyak 6 siswa atau $16,66 \%$, jumlah kesalahan tipe $\mathrm{C}$ sebanyak 10 siswa atau $28 \%$, jumlah kesalahan tipe T sebanyak 11 siswa atau 31\%, jumlah kesalahan tipe P sebanyak 29 siswa atau $81 \%$, dan jumlah jumlah kesalahan tipe E sebanyak 29 siswa atau $81 \%$.

Untuk soal nomor 4 diketahui bahwa jumlah kesalahan tipe R sebanyak 2 siswa atau 6\%, jumlah kesalahan tipe C sebanyak 10 siswa atau 28\%, jumlah kesalahan tipe $\mathrm{T}$ sebanyak 11 siswa atau 31\%, jumlah kesalahan tipe P sebanyak 12 siswa atau 33\%, dan jumlah jumlah kesalahan tipe E sebanyak 12 siswa atau $33 \%$.

Untuk soal nomor 5 diketahui bahwa jumlah kesalahan tipe R sebanyak 2 siswa atau 6\%, jumlah kesalahan tipe $\mathrm{C}$ sebanyak 20 siswa atau 56\%, jumlah kesalahan tipe $\mathrm{T}$ sebanyak 8 siswa atau 22,22\%, jumlah kesalahan tipe P sebanyak 22 siswa atau $62 \%$, dan jumlah jumlah kesalahan tipe E sebanyak 24 siswa atau $67 \%$.

Dari 36 siswa tersebut dikelompokkan berdasarkan nilai yang diperoleh dari hasil tes, sehingga diperoleh jumlah siswa pada kategori berkemampuan sangat tinggi sebanyak 3 subjek penelitian atau 8\% yaitu: AH, MDN, dan SRP. Untuk siswa pada kategori berkemampuan kelompok tinggi sebanyak 12 subjek penelitian atau 33\% yaitu: IFM, NPP, UAS, GMC, MC, AFG, NVU, SRA, ASS, DSU, MT, dan MNH. Untuk siswa pada kategori berkemampuan kelompok sedang sebanyak 10 subjek penelitian atau 28\% yaitu: NB, RAS, TYH, DGW, SCF, AKM, SAF, PM, AEW, NW. Untuk siswa pada kategori berkemampuan kelompok rendah sebanyak 6 subjek penelitian atau 17\% yaitu: NB, RAS, TYH, DGW, AKM, SAF, PM, AEW, NW. Dan yang terakhir, untuk siswa pada kategori berkemampuan kelompok sangat rendah sebanyak 5 subjek penelitian atau $14 \%$ yaitu: NA, AMK, RA, AI, NFR. Kemudian peneliti mengambil sebanyak 2 siswa pada setiap kategori kemampuan siswa dalam menyelesaikan soal 
Vol 1 No 22020 Desember 2020

Jurnal AlphaEuclidEdu

statistika tipe HOTS, untuk diwawancarai dengan tujuan mengkonfirmasi terkait analisis yang dilakukan oleh peneliti. Adapun perwakilan dari tingkat kemampuan sangat tinggi adalah $\mathrm{AH}$ dan MDN, tingkat kemampuan tinggi adalah GMH dan MC, tingkat kemampuan sedang adalah PM dan TYH, tingkat kemampuan redah adalah AAS dan IDA, dan tingkat kemampuan sangat rendah adalah NFR dan AI. Berikut hasil kesalahan yang siswa lakukan dalam menuntaskan soal statistika tipe HOTS yang akan disajikan dalam bentuk tabel berdasarkan tingkat kemampuan siswa dalam menyelesaikan soal statistika tipe HOTS.

Tabel 1. Data Hasil Tes Soal Statistika Tipe HOTS Berdasarkan Kategori Kemampuan

\begin{tabular}{|c|c|c|c|c|c|c|c|c|c|}
\hline \multirow{2}{*}{$\begin{array}{c}\text { Tingkat } \\
\text { Kemampuan } \\
\text { Siswa }\end{array}$} & \multirow{2}{*}{ No } & \multirow{2}{*}{$\begin{array}{l}\text { Kode } \\
\text { Nama }\end{array}$} & \multirow{2}{*}{ Soal } & \multicolumn{5}{|c|}{$\begin{array}{c}\text { Kesalahan Berdasarkan } \\
\text { tipe Newman }\end{array}$} & \multirow{2}{*}{$\begin{array}{c}\text { Kesalahan } \\
\text { yang } \\
\text { dilakukan } \\
\text { siswa }\end{array}$} \\
\hline & & & & $\mathbf{R}$ & C & $\mathbf{T}$ & $\mathbf{P}$ & $\mathbf{E}$ & \\
\hline \multirow{10}{*}{$\begin{array}{l}\text { Sangat } \\
\text { Tinggi }\end{array}$} & \multirow{5}{*}{1} & \multirow{5}{*}{$\mathbf{A H}$} & 1 & - & $\boldsymbol{V}$ & - & $V$ & $V$ & C, P, E \\
\hline & & & 2 & - & - & - & - & - & - \\
\hline & & & 3 & - & - & - & - & - & - \\
\hline & & & 4 & - & - & - & - & - & - \\
\hline & & & 5 & - & $V$ & - & $V$ & $V$ & C, P, E \\
\hline & \multirow{5}{*}{2} & \multirow{5}{*}{ MDN } & 1 & - & - & - & - & - & - \\
\hline & & & 2 & - & - & - & - & - & - \\
\hline & & & 3 & - & $V$ & - & $\boldsymbol{V}$ & $V$ & C, P, E \\
\hline & & & 4 & - & - & - & - & - & - \\
\hline & & & 5 & - & - & - & - & - & - \\
\hline \multirow{10}{*}{ Tinggi } & \multirow{5}{*}{3} & \multirow{5}{*}{ GMH } & 1 & - & - & - & - & - & - \\
\hline & & & 2 & - & - & - & - & - & - \\
\hline & & & 3 & - & - & - & $V$ & $V$ & P, E \\
\hline & & & 4 & - & - & $V$ & $V$ & $V$ & $T, P, E$ \\
\hline & & & 5 & - & $V$ & - & $V$ & $V$ & C, P, E \\
\hline & \multirow{5}{*}{4} & \multirow{5}{*}{ MC } & 1 & - & $V$ & - & $\boldsymbol{V}$ & $V$ & C, P, E \\
\hline & & & 2 & - & - & $V$ & $V$ & $V$ & T, P, E \\
\hline & & & 3 & - & - & - & - & - & - \\
\hline & & & 4 & - & - & - & - & - & - \\
\hline & & & 5 & - & $V$ & - & $V$ & $V$ & C, P, E \\
\hline \multirow{10}{*}{ Sedang } & \multirow{5}{*}{5} & \multirow{5}{*}{ TYH } & 1 & - & $V$ & - & $V$ & $V$ & C, P, E \\
\hline & & & 2 & - & $V$ & $V$ & $V$ & $V$ & C, T, P, E \\
\hline & & & 3 & - & - & - & - & - & - \\
\hline & & & 4 & - & - & - & - & - & - \\
\hline & & & 5 & - & $V$ & $V$ & $V$ & $V$ & C, T, P, E \\
\hline & \multirow{5}{*}{6} & \multirow{5}{*}{ PM } & 1 & - & $V$ & - & $V$ & $V$ & C, P, E \\
\hline & & & 2 & - & $V$ & $V$ & $V$ & $V$ & C, T, P, E \\
\hline & & & 3 & - & - & - & - & - & - \\
\hline & & & 4 & - & - & - & - & - & - \\
\hline & & & 5 & - & $V$ & $V$ & $\boldsymbol{V}$ & $V$ & C, T, P, E \\
\hline \multirow{2}{*}{ Rendah } & \multirow{2}{*}{7} & \multirow{2}{*}{ IDA } & 1 & - & $V$ & $V$ & $V$ & $V$ & C, T, P, E \\
\hline & & & 2 & - & - & $\boldsymbol{V}$ & $\boldsymbol{V}$ & $V$ & $\mathbf{T}, \mathbf{P}, \mathbf{E}$ \\
\hline
\end{tabular}


Vol 1 No 22020 Desember 2020

Jurnal AlphaEuclidEdu

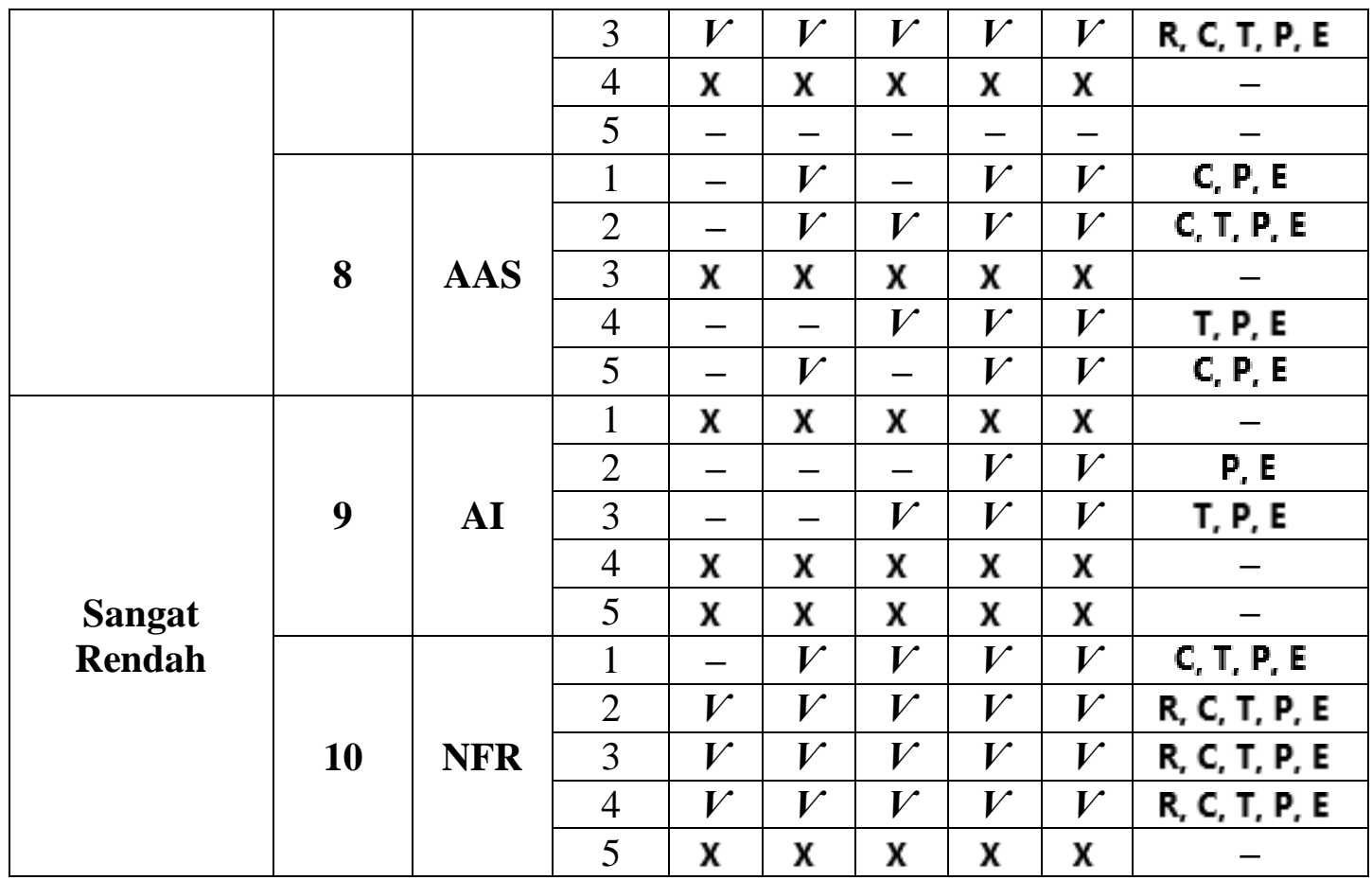

Berdasarkan tabel 1. siswa dengan kemampuan sangat tinggi yaitu AH dan MDN sama-sama melakukan kesalahan: tipe $\mathrm{C}$, tipe $\mathrm{P}$ dan tipe $\mathrm{E}$, ini dikarenakan siswa $\mathrm{AH}$ bingung membedakan rata-rata sebelum 5 siswa mengulang dan rata-rata setelah 5 orang mengulang. seharusnya rata-rata sebesar 7,2 itu rata-rata sebelum 5 siswa mengulang dan untuk rata-rata 7,4 adalah rata-rata nilai setelah 5 siswa mengulang. Selain itu, AH tergesah-gesah dalam proses perhitungan sehingga menyebabkan hasilnya salah. Sedangkan untuk hasil akhir yang ditulis tidak sesuai dengan yang dimaksud dari pertanyaan. Untuk siswa MDN tidak paham informasi yang terdapat dalam soal, MDN tidak mengetahui poin-poin penting pertanyaan dalam soal, sehingga salah dalam proses perhitungan, hal tersebut mengakibatkan siswa MDN tidak sesuai dalam memberikan jawaban akhir. Dalam hal ini siswa dengan kategori berkemampuan tinggi lebih banyak melakukan kesalahan tipe $\mathrm{P}$ dan tipe $\mathrm{E}$.

Untuk siswa dengan kemampuan tinggi yaitu GMH dan MC melakukan kesalahan: tipe $\mathrm{C}$, tipe $\mathrm{P}$, tipe $\mathrm{T}$ dan tipe $\mathrm{E}$. Untuk kesalahan tipe $\mathrm{C}$ yang siswa $\mathrm{GMH}$ lakukan, lantaran siswa GMH tidak dapat memasukkan poin-poin penting yang ada pada soal ke dalam rumus matematika, tepatnya pada rumus statistika. Siswa GMH pada proses perhitungan tidak melanjutkannya, sehingga GMH melakukan kesalahan tipe $P$. Sedangkan untuk kesalahan tipe E, siswa GMH kurang lengkap dalam menuliskan jawaban akhir, sehingga terjadi kesalahan tipe E yang siswa GMH lakukan.

Sedangkan untuk siswa MC kesalahan tipe C yang dilakukannya terjadi karena siswa MC terbalik dalam menuliskan informasi penting, dimana nilai 7,4 seharusnya rata-rata setelah adanya pengulangan, sedangkan nilai 7,2 adalah nilai sebelum adanya pengulangan. Sehingga berakibat proses perhitungan siswa MC menjadi salah. Oleh karena itu siswa MC juga melakukan kesalahan tipe P. Sedangkan untuk kesalahan tipe E yang siswa MC lakukan yakni tidak lengkap memberikan jawaban akhir dan siswa MC salah menuliskan kesimpulan jawaban yang diberikan.

Untuk siswa dengan kemampuan sedang yaitu TYH dan PM melakukan kesalahan tipe $\mathrm{C}$, tipe $\mathrm{T}$, tipe $\mathrm{P}$, dan tipe $\mathrm{E}$. Untuk siswa TYH melakukan kesalahan: tipe $\mathrm{C}$, tipe $\mathrm{T}$, 
tipe $\mathrm{P}$, dan tipe E. Hal ini dikarenakan siswa TYH tidak paham maksud soal nomor 2 ia hanya sebatas mengetahui nilai akhir standar deviasi dikalikan 2 dan kemudian dikurangi 15, akan tetapi siswa TYH tidak mampu memasukkan poin-poin penting kedalam rumus statistika. Akibatnya siswa TYH melakukan kesalahan tipe C dan tipe T. untuk tipe $\mathrm{P}$ dan tipe E, siswa TYH salah dalam perhitungan, ia tidak dapat menjalankan prosedur penyelesaian dengan tepat serta jawaban yang diberikan siswa TYH tidak sesuai. Hal ini menyebabkan siswa TYH kurang tepat.

Sedangkan untuk siswa PM melakukan kesalahan tipe C, tipe P dan tipe E. Untuk kesalahan tipe $\mathrm{C}$ yang dilakukan siswa PM terjadi disebabkan oleh kebingungan siswa PM dalam membedakan rata-rata sebelum 5 siswa mengulang dan rata-rata setelah 5 orang mengulang. seharusnya rata-rata sebesar 7,2 itu rata-rata sebelum 5 siswa mengulang dan untuk rata-rata 7,4 adalah rata-rata nilai setelah 5 siswa mengulang. Selain itu, siswa PM terburu-buru dalam proses perhitungan sehingga menyebabkan hasilnya salah. Sehingga jawaban akhir yang siswa PM tuliskan tidak sesuai dengan permintaan soal. Terlepas dari kesalahan tipe $\mathrm{C}$ tersebut, siswa PM juga melakukan kesalahan tipe P. Dimana dalam perhitungannya siswa PM salah dalam menghitung $\frac{294}{40}$ yang seharusnya diperoleh 7,35 akan tetapi justru siswa PM menuliskan 7,5. Hal ini menyebabkan siswa PM salah dalam memberikan jawaban akhir yang tepat. Sehingga tipe $\mathrm{P}$ dan tipe $\mathrm{E}$ lebih dominan dilakukan oleh siswa yang berkemampuan sedang seperti yang diuraikan diatas.

Untuk siswa dengan kemampuan rendah yaitu IDA dan AAS melakukan kesalahan: tipe R, tipe C, tipe T, tipe P, dan tipe E. Siswa IDA melakukan kesalahan: tipe R, tipe C, tipe $\mathrm{T}$, tipe $\mathrm{P}$ dan tipe E. Untuk tipe R, siswa IDA tidak mengetahui istilah, lambang, ataupun simbol yang terdapat dalam soal. Siswa IDA tidak mengetahui istilah standar devisiasi, ia bingung membedakannya antara simpangan baku dan simpangan rata-rata. Untuk tipe C, siswa IDA melakukan kesalahan dikarenakan ia menyelesaikannya soal nomor 2 dengan cara mencari terlebih dahulu berapa mahasiswa yang lulus dari informasi $60 \%$ sehingga diperoleh 180 mahaiswa yang dinyatakan lulus, akibatnya interval data terletak pada 66 - 75. Kemudian siswa IDA langsung berkesimpulan bahwa nilai terendahnya tu 66. Ini berarti siswa IDA tidak mampu memahami soal dengan benar. Untuk tipe T, siswa IDA sudah benar dalam menentukan rumus yang digunakan, akan tetapi siswa IDA belum bisa memasukkan data yang ada ke dalam rumus statistika yang digunakan. Untuk tipe $\mathrm{P}$, proses perhitungan yang dilakukan siswa IDA masih tidak tepat. Untuk tipe E, terjadi ketika jawaban akhir yang diberikan siswa IDA jawaban yang kurang tepat dan kurang lengkap. Siswa IDA menuliskan " $3 \%$ atau $9 \%$ " dimana seharusnya tertulis $3 \%$ atau $8 \%$ " sehingga siswa IDA kurang tepat dalam memberikan jawaban.

Sedangkan siswa AAS melakukan kesalahan: tipe $\mathrm{C}$, tipe $\mathrm{T}$, tipe $\mathrm{P}$ dan tipe $\mathrm{E}$. Untuk tipe $\mathrm{C}$, siswa AAS bingung membedakan rata-rata sebelum 5 siswa mengulang dan rata-rata setelah 5 orang mengulang, seharusnya rata-rata sebesar 7,2 itu rata-rata sebelum 5 siswa mengulang dan untuk rata-rata 7,4 adalah rata-rata nilai setelah 5 siswa mengulang. Untuk tipe P, terjadi dikarenakan siswa AAS salah dalam mengoperasikan operasi pembagian. Untuk tipe E, terjadi dikarenakan siswa AAS hanya menuliskan jawaban "3\%" yang seharusnya tertulis " $3 \%$ atau $8 \%$ ". Siswa tidak menduga bahwa ada kemungkinan lain yang dipertanyakan dalam soal. Sehingga dari penjabaran diatas dapat disimpulkan bahwa kesalahan tipe $\mathrm{C}$, tipe $\mathrm{T}$, tipe $\mathrm{P}$, dan tipe $\mathrm{E}$ lebih dominan dilakukan siswa berkemampuan sedang yang dilanjutkan. 
Untuk siswa dengan kemampuan sangat rendah yaitu AI dan NFR melakukan kesalahan tipe $\mathrm{R}$, tipe $\mathrm{C}$, tipe $\mathrm{T}$, tipe $\mathrm{P}$, dan tipe $\mathrm{E}$. Untuk siswa AI melakukan kesalahan: tipe $\mathrm{T}$, tipe $\mathrm{P}$, dan tipe $\mathrm{E}$. Untuk tipe $\mathrm{T}$, siswa AI tidak mengetahui rumus dari standar deviasi sehingga siswa AI tidak bisa memasukkan informasi penting kedalam rumus. Untuk tipe $\mathrm{P}$, siswa AI tidak mempunya cukup waktu untuk menyelesaikan soal, ia tergesah-gesah dalam melakukan perhitungan terutama pada operasi perpangkatan dan perkalian, ia tidak teliti dalam menghitungnya. Untuk tipe E, siswa AI salah menuliskan jawaban akhir yang diminta, karena pada proses perhitungan siswa AI sudah salah.

Sedangkan untuk siswa NFR, melakukan kesalahan: tipe R, tipe T, tipe C, tipe $\mathrm{P}$, dan tipe E. Untuk tipe R, siswa NFR tidak mengetahui istilah, lambang, ataupun simbol yang terdapat dalam soal. Siswa NFR tidak mengetahui istilah standar devisiasi, siswa NFR tidak pernah mendengar atau menjumpai istilah standar deviasi. Untuk tipe $\mathrm{C}$, siswa NFR bingung membedakan rata-rata sebelum 5 siswa mengulang dan rata-rata setelah 5 orang mengulang, seharusnya rata-rata sebesar 7,2 itu rata-rata sebelum 5 siswa mengulang dan untuk rata-rata 7,4 adalah rata-rata nilai setelah 5 siswa mengulang. Untuk tipe T, karena siswa NFR bingung membedakan rata-rata sebelum dengan sesudah yang terdapat dalam soal, maka siswa NFR juga salah dalam memasukkan informasi penting yang terdapat dalam soal. Untuk tipe P, siswa NFR salah menentukan batas atas dengan batas akhir, sehingga ketika proses perhitungannya menjadi tidak benar. Untuk tipe E, siswa NFR memberikan jawaban tidak benar dikarenakan ketika proses perhitungannyapun salah. Dalam hal ini siswa dengan kategori berkemampuan sangat rendah lebih banyak melakukan kesalahan tipe $\mathrm{C}$, tipe $\mathrm{P}$ dan tipe E.

\subsection{Pembahasan}

Berdasarkan perolehan penelitian diatas, menunjukkan tengah ada siswa yang melakukan kesalahan dalam menuntaskan soal yaitu kesalahan: tipe $\mathrm{R}$, tipe $\mathrm{C}$, tipe $\mathrm{T}$, tipe $\mathrm{P}$, dan tipe $\mathrm{E}$. Tipe $\mathrm{P}$ dan Tipe $\mathrm{E}$ adalah kesalahan yang paling dominan dilakukan siswa. Dari penelitian yang dilakukan oleh Maya Mulyani dan Dedi Muhtadi (2019) tentang analisis kesalahan siswa menyelesaikan soal tipe HOTS pada materi trigonometri ditinjau dari gender diperoleh bahwa berdasarkan kategori kesalahan Newman, letak tahapan kesalahan siswa dalam menyelesaikan soal trigonometri yaitu kesalahan: tipe $\mathrm{T}$, tipe $\mathrm{P}$, tipe $\mathrm{C}$, dan tipe $\mathrm{E}$.

Penelitian lainnya Wilda Mahmudah (2018) tentang berdasarkan teori Newman peneliti ini melakukan analisis kesalahan siswa dalam menyelesaikan soal matematika bertipe HOTS. Berdasarkan teori Newman diperoleh bahwa kesalahan tipe $\mathrm{C}$ dan tipe $\mathrm{T}$ lebih dominan dibandingkan dengan 5 kesalahan lainnya. Dalam penelitiannya persentase kesalahan yang diperoleh adalah $8,5 \%$ siswa melakukan kesalahan tipe $\mathrm{P}$, $30 \%$ siswa melakukan kesalahan tipe $\mathrm{T}, 65 \%$ siswa melakukan kesalahan tipe C, dan $10 \%$ siswa melakukan kesalahan tipe E.

Adapun penelitian lainnya oleh Kharisah imroatul Mu'minah (2018) yang mengungkap kesalahan siswa menyelesaikan soal matematika pada pokok materi 
Vol 1 No 22020 Desember 2020

Jurnal AlphaEuclidEdu

barisan aritmatika sosial tipe HOTS, diperoleh bahwa pada aspek C4 siswa melakukan kesalahan tipe $\mathrm{C}$ dan tipe $\mathrm{T}$, pada aspek $\mathrm{C} 5$ siswa melakukan kesalahan tipe $\mathrm{C}$ dan tipe T, sedangkan pada aspek C6 siswa melakukan kesalahan tipe T saja.

Berdasarkan tujuan penelitian, yang ingin mengungkap kesalahan yang siswa lakukan ini diperoleh kesalahan-kesalahan yang sama, hanya saja untuk persentase pada kesalahan siswa ketika menyelesaikan soal tipe HOTS pada materi statistika berbedabeda. Dan tentunya dengan faktor yang berbeda-beda pula

\section{Kesimpulan}

Berdasarkan perolehan dan pembahasan penelitian pada bab IV, maka dapat diambil kesimpulan bahwa kesalahan yang dilakukan siswa pada penelitian ini mencakup semua jenis kesalahan berdasarkan Newman's Error Analyisis. Kesalahan dari yang tertinggi diantaranya kesalahan keterampilan proses (P), kesalahan jawaban akhir (E), kesalahan memahami masalah (C), kesalahan transformasi (T), kesalahan membaca (R). Untuk tipe $\mathrm{P}$ dan tipe $\mathrm{E}$ adalah tipe kesalahan yang dominan dilakukan siswa. Siswa melakukan kesalahan tipe $\mathrm{P}$ dan tipe $\mathrm{E}$ dikarenakan tidak meneruskan penyelesaian atau mengalami kemacetan dalam perhitungan, serta ketika jawaban akhir yang tertulis tidak tepat atau jawaban akhir yang tertulis tidak sesuai dengan yang dinginkan soal. Untuk kesalahan di masing-masing tingkatan kemampuan sebagai berikut: (1) Kesalahan yang dilakukan siswa dengan kemampuan tergolong sengat tinggi dalam menyelesaikan soal statistika tipe HOTS adalah kesalahan tipe C, tipe P, dan tipe E. Untuk tipe $\mathrm{P}$ dan tipe $\mathrm{E}$ adalah tipe kesalahan yang dominan dilakukan siswa berkemampuan sangat tinggi. (2) Kesalahan yang dilakukan siswa dengan kemampuan tergolong tinggi adalah kesalahan tipe $\mathrm{C}$, tipe $\mathrm{T}$, tipe $\mathrm{P}$, dan tipe $\mathrm{E}$. Untuk tipe $\mathrm{P}$ dan tipe E yakni tipe kesalahan yang dominan dilakukan siswa berkemampuan tinggi. (3) Kesalahan yang dilakukan siswa dengan kemampuan tergolong sedang adalah semua kesalahan yaitu kesalahan tipe $\mathrm{R}$, tipe $\mathrm{C}$ tipe $\mathrm{T}$, tipe $\mathrm{P}$, dan tipe $\mathrm{E}$. Untuk tipe $\mathrm{C}$, tipe $\mathrm{P}$ dan tipe E yakni tipe kesalahan yang dominan dilakukan siswa berkemampuan sedang. kemudian dilanjutkan dengan kesalahan tipe $T$ dan tipe R. (4) Kesalahan yang dilakukan siswa dengan kemampuan tergolong rendah adalah semuanya yaitu kesalahan tipe $\mathrm{C}$, tipe $\mathrm{T}$, tipe $\mathrm{P}$, dan tipe E. Adapun jenis kesalahan yang lumrah dilakukan siswa dengan kemampuan rendah adalah kesalahan, tipe $\mathrm{C}$, tipe $\mathrm{T}$, tipe $\mathrm{P}$, dan tipe $\mathrm{E}$. (5) Kesalahan yang dilakukan siswa dengan kemampuan tergolong tinggi adalah semuanya yaitu kesalahan tipe $\mathrm{R}$, tipe $\mathrm{C}$, tipe $\mathrm{T}$, tipe $\mathrm{P}$, dan tipe $\mathrm{E}$. Adapun jenis kesalahan yang lumrah dilakukan siswa dengan kemampuan sangat rendah adalah kesalahan, tipe C, tipe $\mathrm{T}$, tipe $\mathrm{P}$, dan tipe $\mathrm{E}$. lantas dilanjutkan dengan kesalahan tipe $\mathrm{R}$.

\section{Referensi}

Anderson, L. W., \& Krathwohl, D. R. (Eds.). (2001). A taxonomy for learning, teaching, and assessing: A revision of Bloom's Taxonomy of Educational Objectives (Complete ed.). New York: Longman.

Brookhart, S.M. (2010). How to assess higher-order thingking skills in your classroom. Virginia USA: ASCD Alexandria. 
Vol 1 No 22020 Desember 2020

Jurnal AlphaEuclidEdu

Clemen, M. N. (1980). The Newman Procedure For Analysing Errors On Written Mathematical Tasks. Educational Studies in Mathematics Computer Applicationsin Engineering Sciences. 2(1): 17-21.

Freudenthal, H. (1991). Developing Realistics Mathematics Education. Utrecht: CD-B Press. Freudenthal Institute.

Laporan Hasil Ujian Nasional dari Pusat Penilaian Pendidikan Kementrian Pendidikan dan Kebudayaan (Online) (https://hasilun.puspendik.kemdikbud.go.id/\#2019 Diambil pada tanggal 16 juli 2019).

Mahmudah, Wilda. (2018). Analisis Kesalahan Siswa dalam Menyelesaikan Soal Matematika Tipe HOTS Berdasarkan Teori Newman. Jurnal UJMC 4 (1): 49-56.

Miles, M.B and A. Michael Huberman. (2005). Qualitative Data Analysis (terjemahan). Jakarta: UI Press

Mulyadi, Maya dan Dedi Muhtadi. (2019). Analisis Kesalahan Siswa dalam Menyelesaikan Soal Trigonometri Tipe HOTS Ditinjau dari Gender. JPPM 12(1):1-16.

Mu'minah, K I. (2018). Kesalahan Siswa dalam Menyelesaikan Soal Matematika tipe HOTS Pada Pokok Bahasan Aritmatika Sosial. UMS: 1-12.

Sembiring, Suwah dkk. (2012). Matematika Berbasis Pendidikan Karakter Bangsa. Untuk SMA/MA. Kelas XI. Bandung: Yrama Widya

Singh, Parmjit dkk. (2010). The Newman Procedure for Analyzing Primary Four Pupils Errors on Written Mathematical Tasks: A Malaysian Perspective. Procedia Social and Behavioral Sciences 8 (2010) 264-271 International Conference on Mathematics Education Research 2010 (ICMER 2010)

Syahwaludin, M. (2016). Higher Order Thinkhing Skills Siswa pada Materi Statistika Kelas XI IPA MAN 2 Pontianak. Jurnal Pendidikan dan Pembelajaran, 5 (11): 1-10.

Suyitno, Hardi. 2015. Learning Therapy for Students in Mathematics Communication Correctly Based-on Aplication of Newman Procedure (A Cace of Indonesia Student). International of Education and Research). 